\title{
The influence of sensationalist features in television news stories on perceived news quality and perceived sensationalism of viewers in different age groups
}

\author{
Mariska Kleemans, Radboud University, Behavioural Science Institute* \\ Paul G. J. Hendriks Vettehen, Radboud University, Behavioural Science Institute \\ Johannes W. J. Beentjes, University of Amsterdam, Amsterdam School of \\ Communication Research \\ Rob Eisinga, Radboud University, RadboudSCR \\ *Corresponding author: mariska.kleemans@bsi.ru.nl
}

\begin{abstract}
This study investigates whether the decreased trust in news media can be explained by the increase in sensationalism in news. To this end, an experiment was conducted in which viewers $(N=288)$ evaluated sensationalist versus non-sensationalist television news in terms of perceived news quality and perceived sensationalism. Each participant watched four television news stories that varied in the presence of two categories of sensationalism: arousing content and tabloid packaging. Findings showed that sensationalist television news tends to be more negatively evaluated than non-sensationalist news. In addition, critical views on arousing content appeared to be particularly visible among young and middle-aged adults. These findings suggest that the rise of sensationalist news could be an explanation of the declining trust in news media that is witnessed in a number of countries.
\end{abstract}

\section{Keywords}

sensationalism, arousing content, tabloid packaging, news performance

\section{Introduction}

Public evaluations of news performance have declined steadily over the past decades. In the United States, ratings of the press have become dramatically more negative. For instance, people offer more critical evaluations of the news in terms of its accuracy, fairness, and independence (The Pew Research Center, 2013). Comparable trends were found in European countries. As a result, in 2016 only half of the Europeans had trust in information provided by television, whereas trust in the written press (46\%) and Internet (36\%) was even lower (Eurobarometer, 2016).

In the literature, explanations for the decline in the public's evaluation of news performance have primarily been cast in the context of political communication. First, the decline has been conceptualized as being part of a broader tendency to distrust institutions, experts, and politicians (e.g., Bennett, Rhine, Flickinger, \& Bennett, 1999; Jones, 2004, 2005). Second, the decline in evaluations of news performance has been explained by the rise of Internet and non-mainstream news outlets that offer political views that differ from those offered by traditional news media. Consuming online information that argues with and is critical of traditional news media might lead to declining perceptions of news performance for these media (e.g., Jones, 2005; Tsfati \& Ariely, 2013). A third explanation focuses on the role of traditional media, particularly television journalism. According to this explanation, the profit-driven tendency in television journalism to paint a cynical picture of politics by focusing on political scandals, conflicts, incivility in debates, and horserace news may not only have affected trust in politics (the much debated "videomalaise" hypothesis, e.g., Bennett et al., 1999; Habermas, 2006; Mutz \& Reeves, 2005; 
Robinson, 1976) but also trust in the news media themselves (cf. Cho, Shah, Nah, \& Brossard, 2009).

The present study is particularly related to this latter explanation in that it also investigates the impact of profit-based news coverage on news performance. However, it goes beyond profit-driven coverage of "political" news in the sense of news about politics or politicians. Instead, it examines a broader range of techniques that can be used to attract the viewer's attention to a wide range of news topics, that is, the use of sensationalism. Today's news stories unmistakably display an increasing presence of sensationalist characteristics (cf. Hendriks Vettehen, Beentjes, Nuijten, \& Peeters, 2011; Schaefer \& Martinez III, 2009; Slattery, Doremus, \& Marcus, 2001). The question is whether there could be a connection between the rise of sensationalist news and the general decline in the news consumer's evaluation of news performance. News critics often blame today's news for being sensational, exaggerated, inaccurate, unbalanced, and just looking for anything that thrills (e.g., Jones, 2009). However, it is largely unknown whether this opinion is shared by viewers, and consequently, whether the increase in sensationalist news might be an additional explanation of the waning confidence in the news media. For this reason, the current study investigates how viewers perceive the performance of the two categories of sensationalist news characteristics that are commonly distinguished in the literature: arousing content and tabloid packaging.

We will limit our study to television news, because television news still is a major source of news for many citizens in, for instance, the US (cf. The Pew Research Center, 2013) and in Europe (Eurobarometer, 2016) - including the Netherlands (Sociaal Cultureel Planbureau, 2015), where the current study is conducted. Moreover, television news is relevant to study here, because particularly the relatively wide opportunities provided by television's audiovisual character to provide a sensationalist coverage of events have been related to audience evaluations in the polit- ical communications literature described above (the label "videomalaise," e.g., Cho et al., 2009; Mutz \& Reeves 2005).

In all, the current study aims to investigate whether the decreased trust in news media can be explained by the increase in sensationalism in television news. An experiment will be conducted in which participants of varying ages evaluate sensationalist versus non-sensationalist television news. We take the moderating role of age into account, because studies have already revealed differences between older and younger viewers in their preference for sensationalist versus non-sensationalist news (Kleemans, Hendriks Vettehen, Beentjes, \& Eisinga, 2012; Lang et al., 2005). Therefore, this study investigates whether they also have different perceptions of such news.

\section{Sensationalism in news: arousing content and tabloid packaging}

The presence of sensationalist features in news has already been traced back to the 1500s (Stephens, in Grabe Zhou, \& Barnett, 2001). It has been fiercely criticized with regard to, for instance, the Penny Press (cf. Emery, 1962) and Yellow Journalism (cf. Baran \& Davis, 2012). Nevertheless, sensationalist features never disappeared completely from news stories, and trend studies on television news even show that sensationalism increased over the past decades (e.g., Hendriks Vettehen et al., 2011; Hvitfelt, 1994; Slattery et al., 2001; Slattery \& Hakanen, 1994; Schaefer \& Martinez III, 2009). Consequently, scholars pay increasing attention to the causes and consequences of sensationalist news.

In the literature, a number of related concepts have been employed to study the general phenomenon we refer to as "sensationalist news," including infotainment (Graber, 1994), bad news (Newhagen \& Reeves, 1992), soft news (Baum, 2002), tabloidization (Bek, 2004), and arousing news (Kleemans et al., 2012). A number of these studies have defined sensationalist news as news including content and packaging characteristics that have the capability to 
elicit arousal and attention responses in viewers (Grabe, Lang, \& Zhao, 2003; Grabe et al., 2001; Hendriks Vettehen, Nuijten, \& Peters, 2008; Lang, Bolls, Potter, \& Kawahara, 1999). Regarding content, especially survival-relevant stimuli have been regarded as prominent examples. Humans are evolutionary predisposed to survey their environment for potential threats (cf. Davis \& McLeod, 2003; Shoemaker, 1996). Stimuli in news that refer to such threats therefore attract audiences and elicit arousal. Examples are stories and pictures referring to crimes, violence, riots, fires, and disasters (Adams, 1978; Grabe et al., 2001; Newhagen \& Reeves, 1992; Slattery \& Hakanen, 1994). Following Grabe and colleagues (Grabe, Zhou, Lang, \& Bolls, 2000, Grabe et al., 2003) we label this category of sensationalism arousing content.

Packaging characteristics of news stories that may be considered sensational are features that represent change or unexpected occurrences, because they also elicit attention and arousal responses in viewers. For instance, fast pacing, sound effects, music onsets, and decorative editing techniques such as wipes, fades, and dissolves are discerned in this regard (cf. Grabe et al., 2000; Grabe et al., 2003; Hendriks Vettehen, Nuijten, \& Beentjes, 2005; Lang, 2000; Lang et al., 1999). Again following Grabe and colleagues, we label this category of sensationalism tabloid packaging (cf. Grabe et al., 2000, 2003).

\subsection{Assessing the performance of sensationalist news}

The concept of media performance refers to the assessment of mass media using a range of evaluative criteria (McQuail, 1992). However, media performance is a somewhat difficult concept, which has been linked to varying criteria and dimensions. Objectivity is perhaps the most frequently mentioned criterion in assessing news media performance. Other criteria that have often been applied to news are accuracy and completeness, reliability, credibility, factualness, fairness, balance, believability, informativeness, comprehensive coverage, presentation of multiple points of view, and avoidance of sensa- tionalism (Hollifield, 2006; McQuail, 1992; Schatz \& Schulz, 1992).

Differences in grouping of criteria into dimensions have been proposed in past research. For instance, based on core values of the western civilization, McQuail (1992) discerned the performance dimensions of freedom, equality, and cohesion. By contrast, Schatz and Schulz (1992) discerned five dimensions: diversity, relevance, professionalism, legitimacy, and public acceptance. The present study does not seek to take position in questions concerning the precise conceptualization of the concept of media performance. Instead, a number of indicators of media performance have been included in the current study that (a) particularly relate to the performance of television news, and (b) have been used in earlier studies on the performance of sensationalist news.

As far as known, only a few studies investigated whether sensationalist content and packaging of news affected perceptions of TV news performance. In one study (Grabe et al., 2000), viewers watched a number of news stories in either a standard or a tabloid version and subsequently answered a number of evaluative questions about these stories. Results showed that participants perceived the standard packaged stories as more informative and believable. The other study (Grabe et al., 2003) had a similar design, but this time both the content of news stories (arousing versus calm) and packaging of the stories (standard versus tabloid) varied. Results showed that participants perceived the tabloid stories as less believable and less objective than the standard stories, but not as less informative. Arousing content stories were perceived as less informative compared to calm content stories, but not as less objective or less believable. In sum, the two studies provide a preliminary basis to expect that viewers are somewhat skeptical towards the journalistic performance of sensationalist news.

The findings from a correlational study conducted by Wang and Cohen (2009) provide further support for this expectation. This study showed that respondents who estimated the numbers of audio, visual, 
and editing techniques included in television news as being higher, also perceived the news as being more sensationalist. Perceived sensationalism was measured in their study by asking respondents to indicate whether eight concepts (accuracy, responsibility, importance, credibility, professionalism, arousing viewer interest, invading privacy, and gossiping) were inherent in the notion of sensationalism. The latter three concepts were reversed in the analysis, so that a higher score on the constructed scale referred to a higher perception of sensationalism. Because items such as the accuracy, credibility, and importance of a story were included in the scale, their results imply that more tabloid packaging features lead to more negative perceptions of journalistic performance.

The current study extends past research by measuring a greater variety of indicators of news media performance. We will include perceptions of reliability, perceptions of news performance as used by Grabe and colleagues, and several indicators of perceived sensationalism, the central concept in the Wang and Cohen study. Following the general findings in previous research, we pose the following hypotheses:

H1a: Viewers perceive the performance of arousing content news stories as more negative than non-arousing content news stories

H1b: Viewers perceive the performance of tabloid produced news stories as more negative than standard produced news stories

\subsection{Age differences in perceptions of sensationalist news}

No previous research has investigated the moderating role of age, although there are indications that sensationalist news is particularly salient to young people and that young people will therefore have more positive evaluations compared to older people. With regard to digital technologies, Sundar (2008) argues in his MAIN Model that the current generation is more eager to try new formats and is, therefore, more at ease with digital technologies than older people (Sundar, 2008). When they acknowledge technologies as being "hip" or when they are impressed by the novelty of the technology, they may evaluate the message as more credible. As Sundar (2008) states: "If it's cool, it's credible" (p. 82). Moreover, young media users may be enamored by the novelty and therefore perceive such content as being more credible. In addition, the experience that young people have with complex media interfaces may imply that they have a higher threshold for cognitive overload or overstimulation than older people. Therefore, young people are expected to have more positive evaluations of new digital formats compared to older people.

A similar argument can be built with regard to arousing news content and tabloid packaging. Younger viewers have grown up in a highly arousing media environment (e.g., video games, fast-paced music clips, and movies), while older viewers will have experienced an increase in arousing characteristics in media messages over the years (cf. Tapscott, 2009). Due to this generational difference, young news viewers are more at ease with the increase in arousing content and tabloid produced news. We can thus expect that younger viewers are more positive towards the performance of arousing content and tabloid packaged stories than older viewers. We therefore expect that:

H2a: Older viewers have more negative perceptions regarding the media performance of arousing content (as opposed to non-arousing content) compared to younger viewers

H2b: Older viewers have more negative perceptions regarding the media performance of tabloid produced news stories (as opposed to standard produced news stories) compared to younger viewers 


\section{Material and methods}

\subsection{Stimulus materials}

An experiment was conducted in The Netherlands as part of a larger project on the effects of sensationalist news (cf. Kleemans et al., 2012, Kleemans, Hendriks Vettehen, Eisinga, \& Beentjes, 2014) using 16 Dutch public service news stories as stimulus materials. All stories had been broadcast in the main television news program in The Netherlands, the NOS Journaal. The stories were selected out of a pool of news stories that had been content analyzed in a previous study on the presence of arousing content and tabloid packaging features in news stories (cf. Hendriks Vettehen et al., 2012). As shown in Table 1, the intercoder reliabilities of this content analysis were generally acceptable (i.e., above .67) or good (i.e., above .80; Krippendorff, 2004). Exceptions were the reliabilities for the "wipes" and "dissolves," which where slightly lower, but these can be explained by the relatively small sample size and the skewed distribution of these variables (Zhao, Liu, \& Deng, 2012).

Table 1: Coding overview of arousing characteristics in news

\begin{tabular}{ll}
\hline Measures & $\begin{array}{l}\text { Description (Krippendorff's alpha for } \\
\text { intercoder reliabilities) }\end{array}$ \\
\hline Arousing content & \\
Arousing topic & $\begin{array}{l}\text { The presence of at least one of the catego- } \\
\text { ries violence, criminality, accident/disaster, } \\
\text { extremism, unnatural death, sex, drugs, } \\
\text { celebrities, and scandal ( } \alpha=.78)\end{array}$ \\
Arousing pictures & $\begin{array}{l}\text { The number of camera shots in which } \\
\text { pictures of least one of the categories } \\
\text { violence, accident/disaster, people with } \\
\text { physical injuries, death per minute were } \\
\text { present ( } \alpha=.91)\end{array}$ \\
Tabloid packaging & \\
Camera shots & $\begin{array}{l}\text { The number of camera shots per minute in } \\
\text { the news story ( } \alpha=.97)\end{array}$ \\
The number of music onsets in the news \\
Fades
\end{tabular}

The dataset of the content analysis study, containing statistics regarding the presence of sensationalist content and packaging features in a large number of television news stories, was used to select stories that were potentially useful for the experiment. The rationale behind the selection process was that we aimed to maximize the difference between the two types of content and the two types of packaging in the stimulus materials. Therefore, we first selected only stories that included either an arousing story topic combined with arousing pictures or a non-arousing story topic without the presence of any arousing pictures. Second, from this sub-selection we selected the most suitable stories based on the presence or absence of tabloid packaging features: stories including either a very small (i.e., a low number of camera changes and no sound effects, music onsets or decorative editing techniques) or a very large number of tabloid features were selected.

As a final step in the selection process, we selected eight stories out of the pool of remaining stories that included all arousing content indicators and eight stories that included none of them. A number of additional selection criteria were applied to make the final choices, because we wanted to minimize the potential influence of factors other than differences in content and packaging. In particular, we only selected stories that presented local news, had a comparable story length $(M=95.31 ; S D=10.78$, measured in seconds), and did not include production errors or a slip of the tongue by the reporter. In addition, topics that had received a lot of media attention or controversial topics were not incorporated in the stimulus material. We also included only stories that were not particularly relevant for the participants. For instance, we selected stories that took place in other parts of the country than where the participants lived. Finally, only stories that could be matched based on story topic remained for the experiment. As described in Table 2, there thus was a standard produced and a tabloid produced story for each topic. 
Table 2: Overview of the 16 news stories

\begin{tabular}{|c|c|c|c|}
\hline \multicolumn{2}{|l|}{ Arousing Content } & \multicolumn{2}{|l|}{ Non-arousing Content } \\
\hline Tabloid Packaging & Standard Packaging & Tabloid Packaging & Standard Packaging \\
\hline Topic: Fire & Topic: Fire & Topic: Economy & Topic: Economy \\
\hline Story about a fire in a museum & Story about a fire in a house & $\begin{array}{l}\text { Story about the economic } \\
\text { situation in The Netherlands }\end{array}$ & $\begin{array}{l}\text { Story about increase of goods } \\
\text { traffic Port of Rotterdam }\end{array}$ \\
\hline Topic: Riots & Topic: Riots & Topic: Nature & Topic: Nature \\
\hline $\begin{array}{l}\text { Story about riots at the turn of } \\
\text { the year }\end{array}$ & $\begin{array}{l}\text { Story about riots during high } \\
\text { school demonstration }\end{array}$ & $\begin{array}{l}\text { Story about mosquitos on Dutch } \\
\text { Island }\end{array}$ & $\begin{array}{l}\text { Story about buffaloes in Dutch } \\
\text { national parks }\end{array}$ \\
\hline Topic: Accident & Topic: Accident & Topic: Culture & Topic: Culture \\
\hline $\begin{array}{l}\text { Story about an accident during a } \\
\text { demonstration }\end{array}$ & $\begin{array}{l}\text { Story about an explosion in } \\
\text { a cafe }\end{array}$ & $\begin{array}{l}\text { Story about } 40 \text { years public } \\
\text { transport (metro) }\end{array}$ & $\begin{array}{l}\text { Story about Dutch buildings reg- } \\
\text { istered as national monuments }\end{array}$ \\
\hline Topic: Crime & Topic: Crime & Topic: Environment & Topic: Environment \\
\hline $\begin{array}{l}\text { Story about a criminal accused } \\
\text { of being involved in liquidations }\end{array}$ & $\begin{array}{l}\text { Story about a pupil who was } \\
\text { murdered at school }\end{array}$ & $\begin{array}{l}\text { Story about prohibiting transport } \\
\text { of ammonia by train in certain } \\
\text { areas }\end{array}$ & $\begin{array}{l}\text { Story about destruction of } \\
\text { unused domestic appliances }\end{array}$ \\
\hline
\end{tabular}

To make the 16 selected stories suitable for the experiment, the spoken introductions by anchorpersons were replaced by screenshots with written introductions. For each news story, this written introduction summarized in one sentence the information that was originally given by the anchorperson, as viewers needed a short introduction to contextualize the news story. We therewith prevented that the different news anchors would have affected the results. In addition, a few of the 16 stories were edited to enlarge the differences in packaging between the tabloid and standard stories. To be more specific, we added or excluded some camera shots or included music or a sound effect, such as the sound of a siren. After these minor changes, tabloid stories included a significantly larger number $(t[7]=10.73, p=.001)$ of camera shots per minute $(M=14.08$; $S D=1.26)$ compared to standard stories $(M=7.79 ; S D=0.56)$. Moreover, a combination of music onsets, fades, wipes, and dissolves was present in the tabloid packaging stories, but not in the standard produced stories. Although the original stories were edited, they still looked realistic. For example, previous research showed that the mean number of camera shots in news from the NOS Journaal contained $14.72(S D=8.66)$ camera shots per minute, implying that the camera changes for the standard and tabloid packaged stories in the current study felt within one standard deviation from the number reported in the study by Kleemans, Van Cauwenberge, Hendriks Vettehen, and d'Haenens (2008).

\subsection{Participants and procedure}

A total number of 288 higher educated participants $(48.6 \%$ male) took part in the study. To represent young viewers, 96 university students were recruited (age range $18-26$ years, $M=21.70 ; S D=2.05$ ). To represent middle-aged viewers, 96 academic employees took part in the study (30-50 years old, $M=41.91 ; S D=4.85$ ). The oldest group (aged 60 years and above) consisted of 96 former academic employees or other higher educated elderly people $(M=68.82 ; S D=6.98)$.

The 16 news stories that were selected for the experiment were divided into four groups. Each group consisted of four stories, one for each combination of content and packaging. Twenty-four participants of each age category watched the stories of one group. These stories were presented in a random order. The experiment was conducted in an individual setting. Each participant first answered a few general questions about, for instance, age and sex, then watched the first story, and finally answered questions intended to measure perceptions towards the story. This combination of watching a story and answering some questions about it was repeated for the other three stories. 


\subsection{Dependent variables}

Participants were asked to rate seven statements about the perceived news media performance of the stories on a scale ranging from 1 (totally disagree) to 7 (totally agree). Our selection of news media performance indicators was first inspired by previous studies on the topic: participants indicated the extent to which a story was informative, objective, and credible (cf. Grabe et al., 2000, 2003). Second, we included a statement that reflects the central concept as used by Wang and Cohen (2009): perceived sensationalism. Third, we added two indicators that were derived from public discussions regarding the performance of arousing television news (cf. Bernstein, 1992; Fortuyn, 2000; Jones, 2009): exaggerated and blown up. Finally, we assessed the reliability of the story, because this issue reflects the background of the study, namely the decreased public trust in today's news, more directly.

A principal component analysis with oblique rotation of the seven statements was conducted for each type of news story separately. Both Kaiser's criterion of retaining factors with eigenvalues greater than 1 and the criterion of factor loadings greater than .60 (cf. Kline, 1994) implied that two components of perceived news media performance could be discerned. The first, which we labeled perceived news quality, consists of the statements regarding the perceived informativeness, objectivity, credibility, and reliability of the news story. Cronbach's alpha of the items varied between $\alpha=.82$ and $\alpha=.84$ for the four types of news stories. The statements regarding the perceived sensational, exaggerated, and blown up character of the news stories together constitute the second dimension, called perceived sensationalism. Cronbach's alphas varied between $\alpha=.66$ and $\alpha=.76$ for the four types of news stories. For each type of news story, we calculated the participant's mean score to construct the variables perceived news quality and perceived sensationalism.

\section{Results}

Repeated measures MANOVAs were carried out for perceived news quality and perceived sensationalism separately, with content (arousing vs. non-arousing) and packaging (tabloid vs. standard) as withinsubjects factors, and age (young, middle, old) as between-subjects factor.

\subsection{Effects of sensationalist news on perceived news performance}

Hypothesis 1a, predicting that viewers perceived the performance of arousing content stories as more negative than non-arousing content stories, was confirmed by the results. Viewers perceived the news quality of non-arousing stories $(M=5.20 ; S E=0.05)$ to be higher than the quality of arousing stories $(M=4.96$; $S E=0.05), F(1.285)=17.40 ; p=.001, r=.24$. In addition, arousing stories $(M=3.34$, $S E=0.06$ ) were perceived as considerably more sensational than non-arousing stories $(M=2.54, S E=0.05), F(1.285)=140.41$; $p<.001, r=.57$.

Hypothesis $1 b$ was partially supported. No significant results of packaging for the perceived quality of the news were found. However, tabloid packaging affected perceived sensationalism, $F(1.285)=21.42 ; p<.001, r=.26$. Findings indicated that tabloid produced stories $(M=3.10, S E=0.06)$ were perceived as more sensational than standard produced stories $(M=2.78, S E=0.06)$. The significant interaction between content and packaging, $\quad F(1.285)=16.64 ; p<.001$, further refines this main effect. Post hoc $F$-tests showed that only for non-arousing stories, the inclusion of tabloid features increased perceived sensationalism $(\triangle M=0.58$; $F(1.285)=36.237 ; \quad p<.001, \quad r=.34)$. For arousing content, no significant $(p=.577$ ) increase in perceived sensationalism was found due to packaging.

\subsection{The moderating role of age}

Hypothesis 2a posed the expectation that older viewers had more negative perceptions regarding the media performance of arousing content stories than younger viewers. We found a main effect of age for 
Figure 1: Perceived news quality by content among young, middle-aged, and old viewers

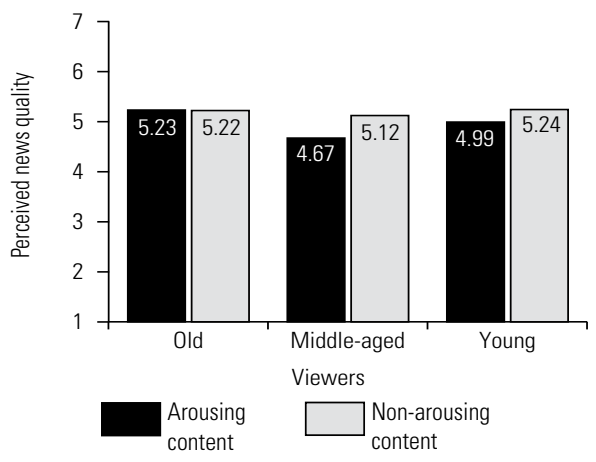

perceived news quality, $F(2.285)=4.92$; $p=.008$, which was further refined by the interaction between content and age, $F(2.285)=5.17 ; p=.006$. As shown in Figure 1 (means reported within bars, $S E=0.09$ for all means), for older viewers there was no difference $(p=.968)$ in perceived news quality between arousing and non-arousing stories. Middle-aged viewers perceived non-arousing stories as having somewhat more news quality than arousing stories, $F(1.285)=20.91 ; p<.001, r=.26$. The same pattern was found for young viewers, $F(1.285)=6.82 ; p<.001, r=.15$.

Regarding perceived sensationalism, a main effect for age was found, $F(2.285)=7.05 ; p=.001$. In addition, an interaction effect between content and age $(F[2.285]=3.63 ; p=.028)$ appeared. Posthoc comparisons showed that participants within all three age categories perceived arousing content stories as more sensational than non-arousing content stories $(F[1.285]=32.88 ; p<.001, r=.32$ for young viewers; $F(1.285)=81.75 ; p<.001, r=.47$ for middle-aged viewers, and $F(1.285)=33.04$; $p<.001, r=.32$ old viewers). However, as Figure 2 shows, middle-aged viewers appear to be a bit more sensitive to arousing news content than older and younger viewers (means reported within bars, $S E$ varied between 0.09 and 0.11 ).

In all, we need to reject $\mathrm{H} 2 \mathrm{a}$ because younger and middle-aged viewers perceived arousing content stories as having
Figure 2: Perceived sensationalism by content among young, middle-aged, and old viewers

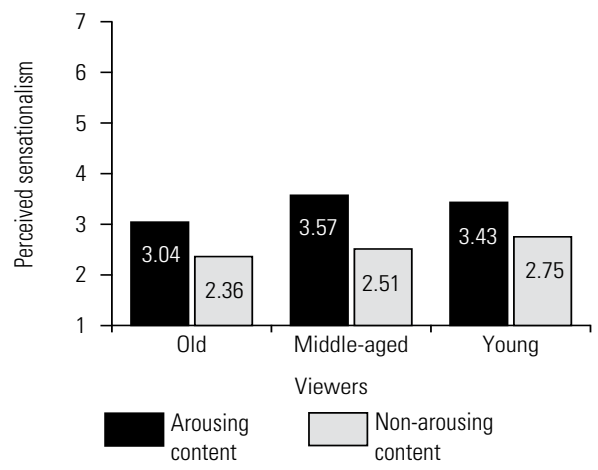

a lower news quality than non-arousing content stories, whereas older viewers perceived arousing content stories as having an equal news quality compared to non-arousing content stories. Moreover, older viewers were less critical regarding the sensational character of arousing content news stories than middle-aged and younger viewers. Hypothesis $2 \mathrm{~b}$ also needs to be rejected because no age differences in viewer perceptions of both news quality and sensationalism with regard to packaging were found.

\section{Discussion}

\subsection{Conclusion}

This study investigated viewer evaluations of sensationalist television news. The most important finding is that arousing content in news tends to be more negatively evaluated (in terms of both perceived news quality and perceived sensationalism) than non-arousing content. In addition, tabloid packaging increased perceptions of sensationalism, but only for non-arousing content stories. The relationship between content of news stories and both perceived news quality and perceived sensationalism varied between viewers of different ages. Critical views on arousing content appeared to be particularly visible among young and middle-aged viewers. 


\subsection{Discussion}

Some unexpected results provide a qualification of our overall conclusion. First, our finding that only tabloid produced stories containing non-arousing content were perceived as more sensational is a bit different from the Wang and Cohen (2009) finding. Moreover, in contrast to Grabe and colleagues $(2000,2003)$, we did not find an effect of packaging on the perceived quality of news stories. This might possibly be explained by the European context in which our study took place. In particular compared to US news stories, Dutch news stories typically do not contain many tabloid features. The absence of effects here might thus be due to relatively smaller differences in our stimulus materials.

Second, the results regarding the moderating role of age were different from what we expected. Not older adults, but young and middle-aged viewers appeared to be more critical on the use arousing content. An explanation may be found in the fact that we selected stories from the main public news program in The Netherlands. For over 60 years, this news program has been seen as a hallmark of high-quality TV news. It could be that older viewers take an acceptable news media performance of this particular news program for granted, since they were raised at a time when the quality of the program was undisputed.

Some critical remarks need to be made. First, only higher educated viewers participated in our study. One might ask whether this limits the degree to which our findings can be generalized. We know from previous research that higher educated viewers have generally more interest in news than lower educated viewers (cf. Ettema \& Kline, 1977; Liu \& Eveland, 2005). Higher educated viewers are thus more motivated to acquire information. One might argue that they are hence more critical towards news performance (cf. Bucy, 2003), which may have somewhat limited the degree to which the results of the current study might be generalized. We recommend including participants with lower educational backgrounds in future research as well.
Another limitation concerns the origin of the stimuli. All stories were broadcast by the same public service broadcaster. Since we know from previous research that commercial broadcasters are more frequently associated with the inclusion of arousing content and tabloid features (Hendriks Vettehen et al., 2005), the results might be somewhat more distinct when using news stories broadcast by commercial channels (cf. Leshner, Reeves, \& Nass, 1998). Future research should, therefore, shed more light on differences in viewer perceptions of news performance between public service and commercial broadcast television news.

Regardless of these limitations, this study contributes to an emerging body of empirical evidence on perceptions of sensationalist television news. Only a few studies had been conducted so far, and each of these studies was somewhat limited. In the Wang and Cohen survey (2009), respondents were questioned about a number of news categories (e.g., crime and conflicts, accidents and disasters), without actually being exposed to these news categories. The Grabe et al. studies $(2000,2003)$ included only a small number of participants and a small number of questions to measure aspects of performance. The current study applied the rigorous experimental methodology from the Grabe et al. studies, while using (a) a more comprehensive set of evaluation questions that empirically allowed for distinguishing two performance dimensions, and (b) a larger number of participants, making it possible to investigate the moderating role of age.

To conclude, the overall study finding that arousing television news content and - to some extent - tabloid packaged television news tends to be more negatively evaluated than non-arousing content and standard packaged news contributes to the debate on the waning confidence in the news media by providing an alternative to existent explanations of distrust. Until now, the broader tendency to distrust institutions, experts, and politicians (e.g., Bennett, et al., 1999; Jones, 2004), the tendency in political coverage to paint a cynical picture of politics 
by focusing on political scandals, politicians' private lives, and horse-race news (Jones, 2005), and the possibility to consume online information that argues with and is critical of traditional news media (e.g., Jones, 2005; Tsfati \& Ariely, 2013) are discerned as factors explaining the declining trust in news media. The current study findings suggest that the increasingly sensationalist character of television news might be an additional explanation of decreased perceptions of news performance.

\section{References}

Adams, W.C. (1978). Local public affairs content on TV news. Journalism Quarterly, 55(4), 690-695. doi: $10.1177 / 107769907805500405$.

Baran, S. J., \& Davis, D. K. (2012). Mass communication theory. Foundations, ferment, and future ( $6^{\text {th }}$ edition). Canada: Wadsworth Cengage Learning.

Baum, M.A. (2002). Sex, lies, and war: How soft news brings foreign policy to the inattentive public. The American Political Science Review, 96(1), 91-109. doi: 10.1017/ S0003055402004252.

Bek, M. G. (2004). Research note: Tabloidization of news media. An analysis of television news in Turkey. European Journal of Communication, 19(3), 371-386. doi: $10.1177 / 0267323104045264$.

Bennett, S. E., Rhine, S. L., Flickinger R. S., \& Bennett, L. L. M. (1999). Video malaise revisited: Public trust in the media and government. The Harvard International Journal of Press/Politics, 4(4), 8-23. doi: 10.1177/1081180X9900400402.

Bernstein, C. (1992). The idiot culture. Reflections of post-Watergate journalism. New Republic, 22-28.

Bucy, E. P. (2003). Media credibility reconsidered: Synergy effects between on-air and online news. Journalism \& Mass Communication Quarterly, 80(2), 247-264. doi: $10.1177 / 107769900308000202$.

Cho, J., Shah, D.V., Nah, S., \& Brossard, D. (2009). "Split screens" and "spin rooms": Debate modality, post-debate coverage, and the new videomalaise. Journal of
Broadcasting \& Electronic Media, 53(2), 242-261. doi: 10.1080/08838150902907827.

Davis, H., \& McLeod, S. L. (2003). Why humans value sensational news. An evolutionary perspective. Evolution and Human Behavior, 24(3), 208-216. doi: 10.1016/S10905138(03)00012-6.

Emery, E. (1962). The press and America. An interpretative history of journalism (2nd ed.). Englewood Cliffs, N. J.: Prentice-Hall.

Ettema, J. S., \& Kline, F. G. (1977). Deficits, differences, and ceilings: Contingent conditions for understanding the knowledge gap. Communication Research, 4(2), 179202. doi: $10.1177 / 009365027700400204$.

Eurobarometer (2016). Eurobarometer 86: Media use in the European Union. Retrieved from http://ec.europa.eu/commfrontoffice/publicopinion/index.cfm/Survey/ getSurveyDetail/search/media/surveyKy/2137.

Fortuyn, W. (2000). De slag om het nieuws [The battle for the news]. Den Haag: SDU.

Grabe, M.E., Lang, A., \& Zhao, X. (2003). News content and form. Implications for memory and audience evaluations. Communication Research, 30(4), 387-413. doi: $10.1177 / 0093650203253368$.

Grabe, M.E., Zhou, S., \& Barnett, B. (2001). Explicating sensationalism in television news: Content and the bells and whistles of form. Journal of Broadcasting \& Electronic Media, 45(4), 635-655. doi: 10.1207/ s15506878jobem4504_6.

Grabe, M.E., Zhou, S., Lang, A., \& Bolls, P.D. (2000). Packaging television news: The effects of tabloid on information processing and evaluative responses. Journal of Broadcasting \& Electronic Media, 44(4), 581-598. doi: 10.1207/ s15506878jobem4404_4.

Graber, D.A. (1994). The infotainment quotient in routine television news: A director's perspective. Discourse \& Society, 5(4), 483-508. doi: 10.1177/0957926594005004004.

Habermas, J. (2006). Political communication in media society: Does democracy still enjoy an epistemic dimension? The impact of normative theory on empirical research. Communication theory, 16(4), 411-426. Doi: 10.1111/j.1468-2885.2006.00280.x. Hendriks Vettehen, P. G. J., Beentjes, J.W. J., Nuijten, K., \& Peeters, A. (2011). Arous- 
ing news characteristics in Dutch television news 1990-2004: An exploration of competitive strategies. Mass Communication \& Society, 14(1), 93-112. doi: $10.1080 / 15205431003615893$.

Hendriks Vettehen, P. G. J., Nuijten, K., \& Beentjes, J.W. J. (2005). News in an age of competition: The case of sensationalism in Dutch television news, 1995-2001. Journal of Broadcasting \& Electronic Media, 49(3), 282-295. doi: 10.1207/ s15506878jobem4903_2.

Hendriks Vettehen, P. G. J., Nuijten, K., \& Peeters, A. (2008). Explaining effects of sensationalism on liking of television news stories. Communication Research, 35(3), 319-338. doi: 10.1177/0093650208315960.

Hollifield, C. A. (2006). News media performance in hypercompetitive markets: An extended model of effects. International Journal on Media Management, 8(2), 60 69. doi: 10.1207/s14241250ijmm0802_2.

Hvitfelt, H. (1994). The commercialisation of the evening news: Changes in narrativ technique in Swedish TV news. Nordicom Review, 15(1), 33-41.

Jones, A.S. (2009). Losing the news. The future of the news that feeds democracy. New York: Oxford University Press.

Jones, D. A. (2005). Shooting the messenger: Explaining public discontent with the news media. Politics \& Policy, 33(2), 242-262. doi: 10.1111/j.1747-1346.2005.tb00642.x.

Jones, D. A. (2004). Why Americans don't trust the media: A preliminary analysis. The Harvard International Journal of Press/Politics, 9(2), 60-75. doi: 10.1177/1081180X04263461.

Kleemans, M., Hendriks Vettehen, P. G. J., Beentjes, J.W. J., \& Eisinga, R. (2012). The influence of age and gender on preferences for negative content and tabloid packaging in television news stories. Communication Research, 39(5), 679-697. doi: $10.1177 / 0093650211414559$.

Kleemans, M., Van Cauwenberge, A., d'Haenens, L., \& Hendriks Vettehen, P. (2008). Op zoek naar verklaringen voor sensatie in het nieuws. Een vergelijking tussen Nederlandse, Vlaamse, Waalse, en Franse televisiejournaals. [Explaining sensationalism in television news. A comparison of Dutch, Flemish, Walloon, and
French news stories]. Tijdschrift voor Communicatiewetenschap, 36(4), 301-319.

Kleemans, M., Hendriks Vettehen, P.G. J., Eisinga, R., \& Beentjes, J.W. J. (2014). Enjoyment of arousing television news: The role of age and sensation seeking. Communications, The European Journal of Communication Research, 39(1), 89-99. doi: 10.1515/ commun-2014-0006

Kline, P. (1994). An easy guide to factor analysis. London: Routledge.

Krippendorff, K. (2004). Content analysis: An introduction to its methodology (2nd ed.). Thousand Oaks, CA: Sage.

Lang, A. (2000). The limited capacity model of mediated message processing. Journal of Communication, 50(1), 46-70. doi: 10.1111/j.1460-2466.2000.tb02833.x.

Lang, A., Bolls, P., Potter, R. F. \& Kawahara, K. (1999). The effects of production pacing and arousing content on the information processing of television messages. Journal of Broadcasting \& Electronic Media, 43(3), 451-475. doi: 10.1080/08838159909364504

Lang, A., Shin, M., Bradley, S. D., Wang, Z., Lee, S., \& Potter, D. (2005). Wait! Don't turn that dial! More excitement to come! The effects of story length and production pacing in local television news on channel changing behavior and information processing in a free choice environment. Journal of Broadcasting \& Electronic Media, 49(1), 3-22. doi: 10.1207/s15506878jobem4901_2.

Leshner, G., Reeves, B., \& Nass, C. (1998). Switching channels: The effects of television channels on the mental representations of television news. Journal of Broadcasting \& Electronic Media, 42, 21-33. doi: $10.1080 / 08838159809364432$.

Liu, Y., \& Eveland, W. P. Jr. (2005). Education, need for cognition, and campaign interest as moderators of news effects on political knowledge: An analysis of the knowledge gap. Journalism \& Mass Communication Quarterly, 82(4), 910-929. doi: $10.1177 / 107769900508200410$.

McQuail, D. (1992). Media performance. Mass communication and the public interest. London: Sage.

Mutz, D. C., \& Reeves, B. (2005). The new videomalaise: Effects of televised incivility on political trust. American Political Sci- 
ence Review, 99(1), 1-15. doi: 10.1017/ S0003055405051452.

Newhagen, J. E., \& Reeves, B. (1992). The evening's bad news: Effects of compelling negative television news images on memory. Journal of Communication, 42(2), 25-41. doi: 10.1111/j.1460-2466.1992. tb00776.x.

Pew Research Center (2013). Amid criticism, support for media's "watchdog" role stands out. Retrieved from http://www. people-press.org/2013/08/08/amid-criticism-support-for-medias-watchdog-rolestands-out/.

Robinson, M.J. (1976). Public affairs television and the growth of political malaise: The case of "The Selling of the Pentagon." American Political Science Review, 70(2), 409-432. doi: 10.2307/1959647.

Schaefer, R. J., \& Martinez III, T. J. (2009). Trends in network news editing strategies from 1969 through 2005. Journal of Broadcasting \& Electronic Media, 53(3), 347-364. doi: $10.1080 / 08838150903102600$.

Schatz, H., \& Schulz, W. (1992). Qualität von fernsehprogrammen. Kriterien und methoden zur beurteilung von programmqualität im dualen fernsehsystem. Media Perspektiven, Vol. 1992(11), 690-712.

Shoemaker, P.J. (1996). Hardwired for news: Using biological and cultural evolution to explain the surveillance function. Journal of Communication, 46(3), 32-47. doi: 10.1111/j.1460-2466.1996.tb01487.x.

Slattery, K. L., Doremus, M., \& Marcus, L. (2001). Shifts in public affairs reporting on the network evening news: A move toward the sensational. Journal of Broadcasting \& Electronic Media, 45, 290-302. doi: 10.1207/s15506878jobem4502_6.

Slattery, K. L., \& Hakanen, E.A. (1994). Sensationalism versus public affairs. Content of local TV news; Pennsylvania revisited. Journal of Broadcasting \& Electronic Media, 38(2), 205-216. doi: $10.1080 / 08838159409364257$.

Sociaal Cultureel Planbureau (2015). Media: Tijd in beeld [Media: Time overview]. Retrieved from: https://www.scp.nl/Publicaties/Alle_publicaties/Publicaties_2015/ Media_tijd_in_beeld

Sundar, S. S. (2008). The MAIN Model: A heuristic approach to understanding technology
Effects on credibility. In M. J. Metzger, A. J. Flanagin, The John D. and Catherine T. MacArthur Foundation Series on Digital Media and Learning. Cambridge, MA: The MIT Press, 73-100.

Tapscott, D. (2009). Grown up digital. How the net generation is changing your world. New York: McGraw-Hill.

Tsfati, Y., \& Ariely, G. (2014). Individual and contextual correlates of trust in media across 44 countries. Communication Research, 41(6), 760-782. doi: $10.1177 / 0093650213485972$.

Wang, T. L., \& Cohen, A.A. (2009). Factors affecting viewers' perceptions of sensationalism in television news: a survey study in Taiwan. Issues \& Studies, 45(2), 125-157.

Zhao, X., Liu, J. S., \& Deng, K. (2012). Assumptions behind inter-coder reliability indices. In C.T. Salmon (Ed.), Communication Yearbook, Vol. 36. New York: Routledge (pp. 419-480). 